\title{
Correction to: Civil society, social change, and a new popular education in Russia
}

\section{W. John Morgan, Irina N. Trofmova, and Grigory A. Kliucharev. Routledge, New York/Abingdon, 2019. 188 pp. Routledge Contemporary Russia and Eastern Europe series, vol. 86. ISBN 978-0-415-70913-2 (hbk), ISBN 978-0-367-53368-7 (pbk), ISBN 978-1-315-88571-1 (eBook)}

\section{Elena Ignatovich ${ }^{1}$}

Published online: 10 November 2021

(c) UNESCO Institute for Lifelong Learning and Springer Nature B.V. 2021

\section{Correction to: International Review of Education https://doi.org/10.1007/s11159-021-09925-7}

In the original publication of the book review, in the second-last paragraph the 10th line should read: "For instance, a claim that "sobornost" and "obshchinnost" ("a principle of social organization"; p. xiv) are interchangeable concepts".

Publisher's Note Springer Nature remains neutral with regard to jurisdictional claims in published maps and institutional affiliations.

The original article can be found online at https://doi.org/10.1007/s11159-021-09925-7.

\section{Elena Ignatovich}

lena.ignatovich@ubc.ca

1 Department of Educational Studies, University of British Columbia (UBC), Vancouver, Canada 